управління розвитком залізничної галузі України у Свроінтеграційному векторі // Вісник економіки транспорту i промисловості. - 2018. - №62. - С. 11 - 20

2. Позднякова Л.О., Котик В.О. Удосконалення стратегії управління підприємством // Вісник економічного транспорту і промисловості. - 2017. №59. - С. 249 - 256

3. Бараш Ю.С. Савицька Т.М. Методичний підхід щодо розподілення витрат на утримання інфраструктури залізничного транспорту. // Вісник економічного транспорту і промисловості. - 2016. - №54. - С. 224-237

4. Дейнека О.Г, Позднякова Л.О. Теоретичні підходи до державного управління і адміністрування залізничного транспорту. // Журнал Українська залізниця. - 2018. - № 7 (61). - С. 21-25
5. Фриск А « Белая Книга»(Транспорт -2003-№14 (182).- с. 5455

6. Закон України « Про особливості утворення публічного акціонерного товариства залізничного транспорту загального користування» від 23.02.2012p.№4442-VI [Електронний pecypc]- Режим доступу: http: // docvment. ua/proosobivostiutvozennqa-pu

7. Дикань, В.Л. Экономика предприятия [Текст]: учеб. пособие / В.Л. Дикань, Е.В. Шраменко, Н.В. Якименко; Укр. держ. акад. залізнич. трансп. - Х.: УкрДАЗТ, 2008. - 170 с.

8. Іванов, Ю. Б. Теоретичні основи конкурентної стратегії підприємства [Текст] : монографія /Іванов Ю.Б., Тищенко О.М., Назарова Г.В.; Харк. нац. екон. ун-т. - Х. : ІНЖЕК, 2006. - 382 с.

\title{
РЕФОРМУВАННЯ УКРЗАЛІЗНИЦІ: СТАН І ОСОБЛИВОСТІ
}

\author{
Єлагін Ю.В., к.е.н., доцент, \\ Брильов Д.І., магістр, \\ Зубарєва Л.А., магістр (УкрДУЗТ)
}

\begin{abstract}
Стаття присвячена аналізу поточного стану $i$ особливостей процесу реформування "Укрзалізници", визначенню основних умов $i$ напрямів досягнення ефективних результатів реформування галузі. Розглянуто особливості змін за основними напрямками реформування: організачійної структури управління, технічного оновлення і державного регулювання. Практично зусилля сконцентровані на одному напрямі реформування- зміні організаційної структури ПАТ "Укрзалізниия" і переході до вертикально інтегрованої форми управління. Поточний стан ПАТ "Укрзалізниия" ускладнив роботу по відправленню продукиії металургійної $i$ аграрної галузей економіки Украӥни. Враховуючи теперішній стан функціонування залізничного транспорту України, питання прискорення реформування залізничного комплексу стоїть сьогодні досить гостро. Потрібне удосконалення прочесу закупівель матеріальних ресурсів; прискорене оновлення рухомого складу, в першу чергу тягового; створення умов, механізму і регламентів участі нових учасників в розвитку техніки $i$ технологій, перевезенні і обслуговуванні клієнтів.
\end{abstract}

Ключові слова: державне регулювання, рухомий склад, структура управління, реформування, залізничний комплекс

(C) Єлагін Ю.В.,

Брильов Д.І.,

Вісник економіки транспорту і промисловості № 63, 2018

Зубарєва Л.А. 


\title{
РЕФОРМИРОВАНИЕ УКРЗАЛИЗНЫЦИ: СОСТОЯНИЕ И ОСОБЕННОСТИ
}

\author{
Слагин Ю.В., к.э.н., доцент, \\ Брилёв Д.И., магистр, \\ Зубарева Л.А., магистр (УкрГУЖТ)
}

Статья посвящена анализу текущего состояния и особенностей процесса реформирования "Укрзализныци", определению основных условий и направлений достижения эффективных результатов реформирования отрасли. Рассмотрены особенности изменений по основным направленям реформирования: организации структуры управления, технического обновления и госудастванного регулирования. В основном усилия сконщентрировань на одном направлении - реформировании организационной структуры ПАО "Укрзализныця " и переходе к вертикально интегрированной форме управления. Текущее состояние ПАО "Укрзализныия" усложнило работу по отправлению продукичи металлургической и аграрной отраслей экономики Украины. Учитывая нынешнее состояние функционирования железнодорожного транспорта Украинь, вопрос ускорения реформирования железнодорожного комплекса стоит сегодня достаточно остро. Необходимо усовершенствование прочесса закупок материальных ресурсов; ускоренное обновление подвижного состава, в первую очередь тягового; создание условий, механизма и регламентов участия новых участников в развитии техники и технологий, перевозках и обслуживании клиентов.

Ключевые слова: государственное регулирование, подвижной состав, структура управления, реформирование, железнодорожный комплекс

\section{THE REFORM OF UKRZALIZNYTSIA.STATE AND SPECIFITIES}

\author{
Elagin Y.V., Ph. D., associate Professor, \\ Zubareiva L.A., Master Degree, \\ Brylov D.I., Master Degree (USURT)
}

This article focuses on the analysis of the current state and specificities of the reform process of "Ukrzaliznytsia». It also defines the main conditions and directions to achieve successful results of the industry reforming. The particularities of changes of the fundamental directions of the reform such as the organization of the management structure, the technological updating and legislative regulation are considered. The concentration of efforts is primarily on the reforming of the organizational structure of «Ukrzaliznytsia» and the transition to vertically-integrated form of governance. The current state of "Ukrzaliznytsia» complicated the work on dispatching metallurgical and agrarian sectors of the Ukrainian economy. Considering the current state of the Ukrainian railway transport functioning, the reform acceleration of the railway complex is required. Changing organizational form of management is a necessary but not sufficient condition for improving the efficiency and competitiveness of the industry in the reform process. Implementation of the new organizational form should be combined with the introduction of effective mechanisms of state regulation, organizational and economic improvements, along with technical and technological improvements in the work of rail transport. It is necessary to improve the process of procurement of material resources; accelerated reform of course rolling stock, primarily of rolling stock traction; the creation of conditions, mechanism and participation

Вісник економіки транспорту і промисловості № 63, 2018 
rules of new members in the development of technology applications, the transportation and customer service.

Key words: state regulation, rolling stock, management structure, reforming, railway complex.

Постановка проблеми. Зміна економічних умов, кризові явища в економіці країни, що поширилися на залізничний транспорт, необхідність залучення інвестицій і впровадження нових технологій, нестабільний фінансовий стан викликають необхідність прискорення реформування залізничної галузі.

Реформування залізничного транспорту України було започатковано прийняттям Концепції реформування транспортного сектору економіки у 2000 році, але практично реформування розпочалося у 2015 році, а його результати поки неможна назвати успішними. Проблеми, 3 перевезенням вантажів залізничним траспортом, які проявилися літом 2018 року , відобразились у статистиці промислового виробництва. За даними Держстату України, 3 червня місяця 2018 року зростання промислового виробництва почало сповільнюватися, а в липні 3 урахуванням сезонного чинника скоротилося по відношенню до червня на $1,3 \%$.

Ключові галузі української промисловості - гірничо-металургійний комплекс, енергетика, хімія, виробництво будматеріалів, а також аграрний сектор сильно залежать від залізниці, яка є для них основним, a часто i безальтернативним перевізником. Оскільки Україна все ще залишається індустріальною державою, уповільнення темпів зростання промисловості неминуче відіб'ється і на динаміці зростання ВВП.

Аналіз останніх досліджень i публікацій та виділення невирішених частин загальної проблеми. Дослідження за останній період даного напрямку здійснювали багато вчених 3 досвідом теоретичних та практичних розробок у галузі економіки залізничного транспорту. Найбільше досліджень пов'язаних з реформуванням залізничного транспорту зробили такі вчені як Бараш Ю. С.[2], Дикань В. Л.[3], Ейтутіс Г. Д [5], Макаренко М. В. [7], та інші. Цими та іншими авторами розглянуто багато проблем i аспектів реформування, але до теперішнього часу аналізу поточного стану і особливостей процесу реформування «Укрзалізниці», його ефективності для економіки, власників та користувачів транспортних послуг зроблено не було.

Формулювання цілей статті (постановка завдання). Метою даної статті $\epsilon$ аналіз поточного стану i особливостей процесу реформування «Укрзалізниці», визначення основних умов і напрямків досягнення ефективних результатів процесів реформування галузі.

Виклад основного матеріалу. Реально процес реформування стартував тільки в 2015 році. 31 грудня 2015 року було утворено ПАТ "Українска залізниця". 3 цієї миті стартували нинішні реформи, які зокрема, передбачають перехід до вертикально інтегрованої компанії 3 властивими для бізнесу принципами управління. Шість залізниць - вже реорганізовані в регіональні філії. Утворюються нові компанії, в компетенцію яких входять ті або інші напрями роботи. ПАТ «Укрзалізниця» створено 5 функціональних філій: «Пасажирська компанія», «Воєнізована охорона», «Центр будівельно-монтажних робіт та експлуатації будівель і споруд», «Енергоремтранс», «Центр діагностики залізничної інфраструктури», а також представництво Товариства в Польщі та Словенії.

Що стосується передбаченого виділення бізнес-напрямів в діяльності 
компанії, то воно йде досить в'яло i фрагментарно. Приміром, першою в 2017 році створена філія "Пасажирська компанія". По прибуткових напрямах діяльності УЗ, пов'язаних 3 вантажоперевезеннями, змін практично немає. Хоча спочатку анонсувалося створення власної компанії-експедитора UZ Forwarding, а також ряду інших.

Угодою про асоціацію України та

EC визначено зобов'язання щодо імплементації 6 директив та 4 регламенти ЄC у сфері залізничного транспорту. Імплементація зазначених актів законодавства передбачає, зокрема, забезпечення прозорості та недискримінаційного доступу до інфраструктури залізничного транспорту всіх підприємств залізничного транспорту, покращення послуг залізничних перевезень пасажирів, сприяння інтеграції української залізничної системи в залізничну систему EC.

У процесі реформування «Укрзалізниця» визначила основні завдання ключових напрямків розвитку[ 9],:

-підвищення комфорту для пасажирів за рахунок модернізації та заміни застарілого рухомого складу, запровадження нових додаткових послуг задовольняючих потреби клієнтів;

- зменшення часу перебування пасажирів у дорозі за рахунок збільшення швидкості руху поїздів, модернізації залізничних ліній та заміни рухомого складу;

$$
\text { підвищення }
$$

якості

обслуговування клієнтів та безпеки шляхом впровадження корпоративних стандартів;

- підвищення рівня сервісу шляхом впровадження та розвитку нових каналів продажу квитків;

- забезпечення прибутковості перевезень за рахунок зниження собівартості та підвищення рентабельності перевезень;

- зменшення строку доставки вантажів за рахунок забезпечення залізниць рухомим складом, здатним істотно підвищити техніко-технологічні показники - підвищення швидкості руху поїздів, збільшення маси поїздів, відстані безоглядового та міжремонтного пробігу транспортних засобів, строку їх експлуатації, підвищення пропускної спроможності залізничних ліній;

- збільшення обсягів перевезень вантажів впровадженням інноваційних транспортних та логістичних технологій;

- підвищення прибутковості перевезень шляхом зниження собівартості та підвищення рентабельності перевезень, удосконалення організації перевезень, подальшої електрифікацї залізничних ліній;

- збільшення конкурентоздатності вантажних перевезень впровадженням нової гнучкої системи тарифів.

Незважаючи на те, що активний процесс реформування триває фактично три роки, ярко вираженими явищами, які гальмують розвиток i ефективне функціонування залізничної галузі залишаються:

1) поєднання функцій державного регулювання і господарської діяльності;

2) слабкий розвиток конкуренції в галузі;

3) суттєве спрацювання основних виробничних фондів;

4) недостатній приток інвестицій в модернізацію і розвиток галузі;

5) збитковість i перехресне субсидування пасажирських перевезень;

6) зростання цін i тарифів на продукцію i послуги, що споживається залізничним транспортом.

Перелічені

фактори перешкоджають подальшому ефективному розвитку i функціонуванню залізничного транспорту.

A за висновками провідних менеджерів та експертів найбільших галузей-експортерів - трансформація ПАТ "Укрзализниця" ускладнила роботу 3 відправлення продукції металургійної i та аграрної галузей економіки України. 
Так відправлення підприємств ArcelorMittal скоротилися на 25\%, компанії вдалося реалізувати лише третину iï планів по відправці концентратів в країни Східної Європи," заявив генеральний директор підприємств ArcelorMittal в Україні і Казахстані Парамжит Калон на конференції Global Outlook 2018 Європейської бізнес асоціації (). Сьогодні на складах українських гірничо-збагачувальних комбінатів накопичені 700 тис. тонн продукції при нормативі в 150 тис. тонн. За серпень підприємства недовантажили своїм контрагентам продукції більш ніж на $\$ 100$ млн. I у вересні підприємства зіткнутися 3 необхідністю скорочувати обсяги виробництва.

За даними експертів IMF Group Ukraine у 2015-2017 роках, через дефіцит потужностей "Укрзалізниці" по перевезенню зернових вантажів, аграрії були вимушені в середньому до $27 \%$ об'єму експортного врожаю доставляти за допомогою автомобільного транспорту. У 2017-му році "Укрзалізниці" зі значними перебоями, але все-таки вдалося виконати 97\% від сформованого попиту на вантажні залізничні перевезення. Різниця в 3\% або 10,5 млн тонн вантажообігу була компенсована за рахунок транспортування зернових на експорт дорожчим автотранспортом. За оцінкою експертів, негативний ефект для сільського господарства від необхідності заміщати ЖД-перевезення автотранспортом склав $321 \$$ млн.

Нарешті міністр транспорту

Омелян визнає, що «Укрзалізниця», яка безпосередньо впливає на 5\% ВВП країни, генерує величезні збитки і для себе, і для суміжних галузей. Так, за останні 2 роки мінімум 25\% продукції або залишається на складах, або не виробляється взагалі, оскільки залізниця не здатна перевести такий обсяг. 3 цієї ж причини на сьогодні перевезено лише $45 \%$ врожаю, решта досі в полях або на елеваторах.

Задекларовані УЗ завдання в процесі реформування покращити якість надання послуг, логістику вантажних перевезень, підвищити обсяги перевезень, ефективність операційної діяльності залізниці, ліквідувати корупцію фактично не виконуються і ситуація не покращується.

Навпаки за останні три роки суттєво погіршились основні експлуата- ційні показники роботи: вантажообіг, обсяг транзитних перевезень, обіг вагону, середньодобова продуктивність вагону, простій під однією вантажною операцією, простій на одній технічні станції, середньодобова продуктивність локомотиву, середньодобовий пробіг локомотиву. Відповідно - не може не погіршуватись фінансовий стан компанії. Рівень доходу компанії збільшується лише завдяки збільшенню тарифів на перевезення вантажів та пасажирів.

Попередній аналіз причин такого становища, вказує на відсутність системного підходу і дуже повільні темпи у проведенні реформування «Укрзалізниці».

Практично

зусилля сконцентровано на одному напрямку реформування - зміні організаційної структури ПАТ «Укрзалізниця» та перехід до вертикально інтегрованої форми управління. Шість залізниць були реорганізовані в регіональні філії, а структура i повноваження центрального апарату УЗ розширені. Станом на березень 2018 року, до структури УЗ входило більше ніж 40 департаментів. Деякі з них явно дублюють один одного:

розвитку,

- Департамент реформування i корпоративного розвитку,

- Департамент корпоративної соціальної відповідальності,

- Департамент корпоративного розвитку,

- Департамент стратегічного розвитку і планування,

Навряд чи можна назвати ефективною систему 3 адміністративною структурою до якої входить більше 40 
департаментів, i наявності дублювання функцій.

Зважаючи на високий ступінь зносу виробничих засобів, який по більшості рухомого складу сягає 90-100\%, ключовим напрямом забезпечення перевезень та відповідно виконання завдань реформування галузі $\epsilon$ техніко- технологічне

оновлення засобів

перевезень та їх обслуговування i насамперед рухомого складу.

За останні 10 років приймались різні програми оновлення рухомого складу залізничноі галузі (Рис.1). Однак жодна 3 них не була виконана навіть на $25 \%$.

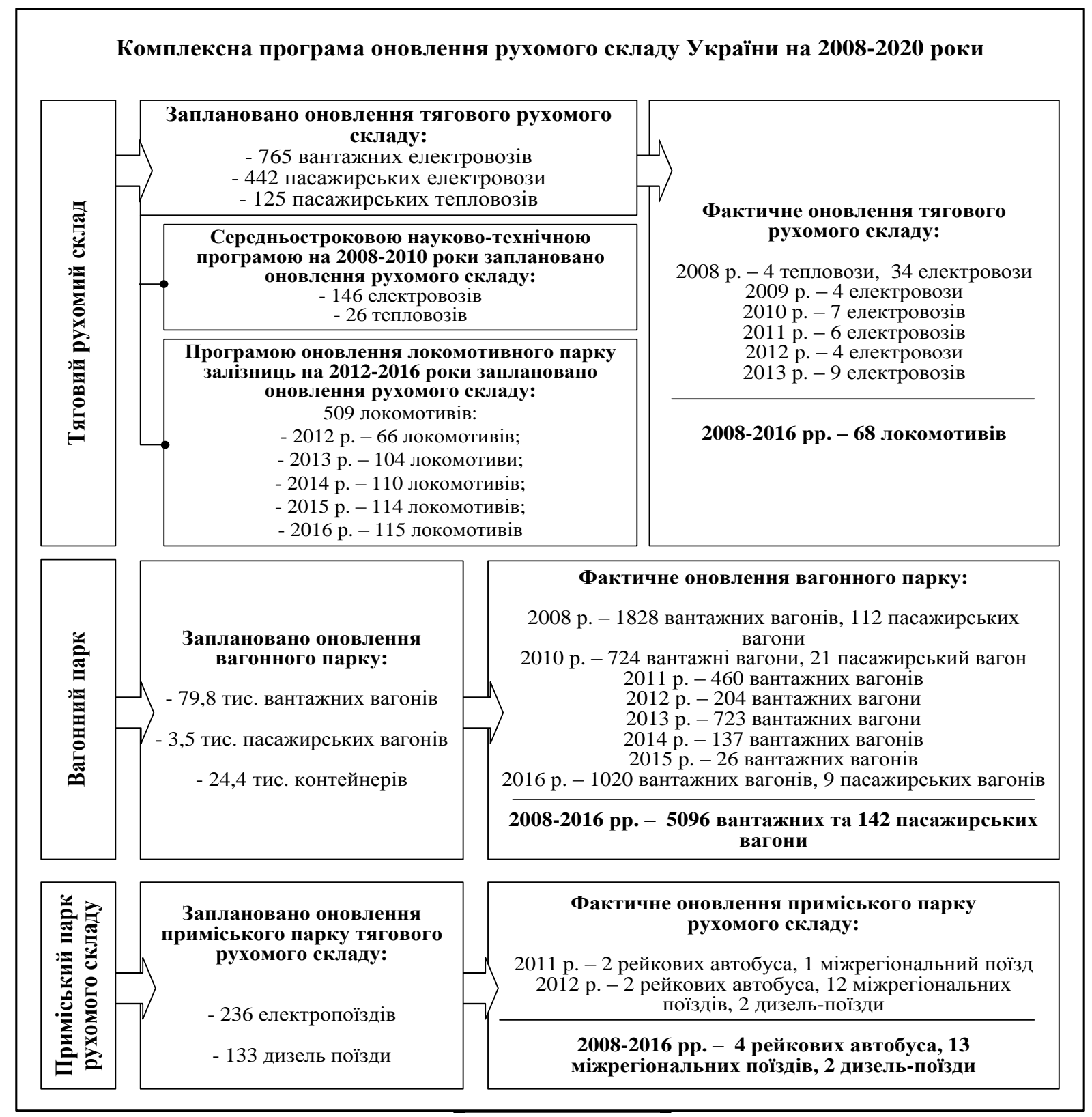

Рис.1 Оновлення рухомого складу ПАТ«Укрзалізниия» [6]

Незважаючи на те, що знос деяких основних засобів вже досяг 100\%, "Укрзалізниця" не поспішає 3 освоєнням необхідних для галузі інвестицій.
Освоєння капітальних інвестицій, за інформацією УЗ: 3 18,4 млрд грн запланованих на 2018 рік інвестицій до рухомого складу освоєно всього біля 3,5 
млрд грн за перше півріччя, тобто 19\% від усієї суми.

Проблема оновлення найбільше стосується тягового рухомого складу від стану якого залежить здатність виконувати перевезення в повному обсязі. На теперішній час згідно інформації, наданої УЗ у відповідь на запит ЦТС, середній вік вантажних електровозів складає 40 років, 3 них вік до 8 років має 31 електровоз, більше 30 років - 857. Середній вік вантажних тепловозів складає 31 рік, при цьому в УЗ немає тепловозів віком меншим ніж 8 років. 297 вантажних тепловозів УЗ старше 30 років. Що стосується пасажирського тягового складу, то середній вік електровозів тут також досягає 40 років. Серед них немає жодного електровозу віком меншим за 8 років. Вік 30 років перевищує 331 електровоз. По пасажирських тепловозах середній вік складає 28 років, локомотиви до 8 років відсутні, старші за 30 років 4 тепловози.

$\mathrm{He}$ останню роль у такому становищі відіграє, довготривале понаднормове знаходження локомотивів у ремонтах через нестачу запчастин

через високий ступінь зносу,а також через складність і тривалість процессу закупівель через систему Prozorro.

При такому стані локомотивного парку, необхідно оновлювати у середньому до 100 локомотивів щороку на протязі 8-10 років.Тож стан тягового рухомого складу потребує різкої активації процесу оновлення.

Реформування

залізничного транспорту це комплексні перетворення, які змінюють законодавчі сторони державних та суспільних відносин функціонування галузі.Реформування передбачає:

інфраструктури від експлуатаційної діяльності, принаймні у фінансовій сфері (повний організаційний поділ не $\epsilon$ обов'язковим); виключення перехресного фінансування збиткових пасажирських перевезень; гарантований на справедливих комерційних умовах вільний доступ до залізничної інфраструктури та створення конкурентного середовища. Ці питання не $\epsilon$ компетенцією Укрзалізниці. Вирішення цих питань має здійснюватися не залізничним транспортом, а органами державної влади України.

На даний момент розроблено нову редакцію Закону України «Про залізничний транспорт України. Законопроект встановлюе принцип рівноправного доступу до послуг інфраструктури, що поширюється на всіх осіб, зацікавлених в отриманні таких послуг.У проекті закріплені основні вимоги, обов'язки та права оператора інфраструктури, перевізника, володільця під'їзних колій, норми щодо управління об'єктами інфраструктури, основні вимоги до залізничного рухомого складу та основи діяльності операторів залізничного рухомого складу.

Але мова йде про проект закону, який виходячи з історії роботи Верховної Ради навряд буде прийнято протягом в передвиборчого року.

3 огляду на поточний стан функціонування залізничного транспорту України , питання прискорення реформування вітчизняного залізничного комплексу стоїть сьогодні досить гостро.

Висновки i пропозиції. Зміна організаційної форми управління $\epsilon$ необхідною, але не достатньою умовою підвищення ефективності i конкурентоспроможності галузі в процесі реформування. Впровадження нової організаційної форми необхідно поєднати 3 впровадженням дієвих механізмів державного регулювання та організаційноекономічними i техніко-технологічними удосконаленнями в роботі залізничного транспорту.[4] Необхідне удосконалення процесів закупівель матеріальнотехнічних ресурсів; прискорене оновлення рухомого складу, насамперед тягового; створення умов, механізму і регламентів участі у розвитку техніки та технологій, перевезеннях та обслуговуванні клієнтів інших учасників. 


\section{ПЕРЕЛІК ВИКОРИСТАНИХ ДЖЕРЕЛ}

1. Закон України «Про особливості утворення публічного акціонерного товариства залізничного транспорту загального користування». [Електронний pecypc].- Режим доступу: https: // zakon.rada.gov.ua/go/4442-17

2. Бараш Ю. С. Обгрунтування оптимальної моделі управління залізничним транспортом // Залізничний транспорт України, 2005. - №9 - С. 208213.

3. Дикань В. Л. Особливості реформування Національної транспортної системи, Дикань В. Л., Єлагіна О. М., // Вісник економіки транспорту i промисловості, 2002. № 1. С. 17-21.

4. Слагін Ю. В. Реформування залізничної галузі: Визначення організаційної структури управління та іiі вплив на конкурентоспроможність // Вісник економіки транспорту i промисловості, 2009. №26 с.22-25.

5. Ейтутіс Г. Д. Міжнародний досвід i практика реформування залізничного транспорту / Ейтутіс Г. Д. Кривошипін О. М., Мукмінова Т. А. //Залізничний транспорт України. - 2007. №2 - C. 31-35.

6. Обруч Г.В. Забезпечення розвитку потенціалу конкурентоспроможності вагонобудівних підприємств України: дис. ... канд. екон. наук: 08.00.04 // Український державний університет залізничного транспорту. Харків, 2017. 265 с.

7. Проблеми та основні напрямки реформування залізничного транспорту України/ Ю. М. Цвєтов, М. В. Макаренко та ін. К. КУЕТТ, 2007. - 222 с.

8. Реформи залізничного транспорту. [Електронний ресурс].Режим доступу: https: // https://mtu.gov.ua/content/reformi-

zaliznichnogo-transportu.html

9. Стратегія ПАТ "Укрзалізниця [Електронний ресурс].- Режим доступу: http://www.uz.gov.ua/about/documents/strate giya/

\title{
СОВЕРШЕНСТВОВАНИЕ ЦЕНООБРАЗОВАНИЯ В ПОРТОВОЙ ОТРАСЛИ УКРАИНЫ
}

\author{
Жихарева В.В., о.э.н., профессор, \\ Онешко С.В., к.э.н. (ОНМУ)
}

В статье предложена классификащия иен на услуги портовых предприятий Украины. Проанализировань причины и следствия снижения эффективности государственного регулирования портовой отрасли в Украине. Разработань направления совершенствования регулирования отрасли и портового иенообразования. Выполнен анализ различных методик расчета ставок портовых сборов, предложен подход $\kappa$ формированию портовых сборов на основе сочетания затратного $и$ коммерческого методов.

Ключевые слова: морские порты, ценообразование, тарифы, портовые сборы, регулирование, логистические затраты, конкурентоспособность. 